\title{
Üreticilerin Toptancı Hallerine ve Hal Yasasına Bakıș Açıları
}

\author{
Yasemin DEMIR
}

Toprak Gübre ve Su Kaynakları Merkez Araștırma Enstitüsü Müdürlüğü, Ankara

\author{
Sorumlu yazar e-mail (Corresponding author e-mail): yasemindemir@tarim.gov.tr \\ Geliș tarihi (Received) : 15.08.2018 \\ Kabul tarihi (Accepted): 26.01.2019 \\ DOI : $10.21657 /$ topraksu.544646
}

\section{Öz}

Bu araștırmanın amacı üretimlerinde yaș meyve ve sebze üretimine yer veren ișletmelerin ürün satıș yerlerindeki tercihleri, toptancı hallerine bakıș açıları ve 5957 sayılı (hal yasası) hakkındaki görüșlerinin belirlenmesidir. Bu amaçlar doğrultusunda Ankara iline bağlı Polatlı, Beypazarı, Ayaș ilçelerinde 122 üretici ile 2016 yılının Nisan-Mayıs aylarında yüz yüze görüșmeler yoluyla anketler yapıımıș ve araștırmanın birincil verilerini olușturmuștur.

Anket sonuçlarını yorumlamak için basit aritmetik ortalama, yüzde hesapları, grafik ve $\chi 2$ analizi kullanılmıștır. Anket yapılan üreticilerin \%95,1'inin 5957 sayılı yasadan haberdar olmadığı ve yasanın içeriği, yapılan değișiklikler ile ilgili bilgi verildikten sonra üreticilerin \%67,1'inin yasadaki değișikliklere olumlu görüș bildirdiği belirlenmiștir. Ancak üreticilerin \% 41 , 8'i toptancı hallerine ürün verme konusunda katı olup, kararlarının değișmeyeceğini bildirmiștir.

Anahtar Kelimeler: Toptancı hal, tarımsal pazarlama, yaș meyve ve sebze

\section{The Opinions of Farmers About the Wholesale Market and Wholesale Market Law}

\begin{abstract}
The purpose of this research is to determine the preferences of the agricultural enterprise that place fresh fruit and vegetable production in the product sales places, the points of view to the wholesale markets and the opinions about law the number 5957. The surveys were completed with 122 farmers in Ankara province in April-May of 2016.

Simple arithmetic mean, percentage calculations, graph and $\chi 2$ analysis were used to interpret the survey results. It was determined that $95,1 \%$ of the farmers were not informed about the number 5957 law, and $67,1 \%$ of the producers reported positive opinions on the changes in law 5957 after informing the contents of the law and the changes made. However, 41,8\% of farmers reported that they are strict about saling products to wholesale markets and that their decisions will not change.
\end{abstract}

Key words: Wholesale markets, agricultural marketing, fresh fruit and vegetable 


\section{Giriș}

Türkiye iklim ve toprak özellikleri itibariyle meyve ve sebze çeșitliliğinin en fazla olduğu sayılı ülkelerdendir. İșlenen 23,9 milyon hektar tarım alanının \%13,7'sinde meyvecilik, zeytincilik ve bağcılık, \%3,4'ünde sadece sebzecilik yapılmaktadır (Anonim, 2016). Türkiye'nin dünya yaș meyve ve sebze üretiminde önemli bir yeri bulunmakta olup, Türkiye yaș meyve ve sebze üretiminde 45, 8 milyon ton üretimi ile Avrupa'da birinci, dünyada ise dördüncü sırada yer almaktadır (Anonim, 2013).

Yaș meyve ve sebze ekonomik öneminin yanı sıra insan beslenmesi açısından vazgeçilmez gereksinimlerdendir. Yaș meyve ve sebzenin üreticiden tüketiciye ulașma sürecinde pazarlama kanalları büyük önem tașımaktadır. Pazarlama zincirinin uzaması ürün fiyatlarının yükselmesine ve haksız rekabete yol açtığı gibi çabuk bozulan bu ürünlerin zayiatına neden olmaktadır. Bu nedenle ekonomik kayıplar artmakta, üretici ve tüketici için olumsuz sonuçlar ortaya çıkmaktadır.

Toptancı halleri haksız rekabeti ortadan kaldırması, ürün fiyatlarını dengelemesi ve kayıt dıșılığı engelleyerek ekonomik kaybı azaltması açısından zincirin en önemli halkası olarak sayılabilir. Toptanci hallerindeki komisyoncular gerek üretici, gerek tüketici taleplerini kavrayarak perakende sektörüne ürün sağlamakta ve ürün kayıplarının azalmasında rol oynamaktadır. Bununla birlikte toptancı halleri aracılığıyla pazarlama masrafları da azalmaktadır. Ancak Türkiye' de yaș meyve ve sebzenin toptancı hallerde ișlem görme oranı yaș meyvede ortalama \%22, sebzede ise \%30 düzeyindedir (Albayrak, 2009). Ayrıca bazı kaynaklarda Türkiye'de yaș meyve ve sebzede üretim ve pazarlama boyutunda ürün kaybının \%20-25 civarında olduğu ifade edilmekte olup, kayıpların hasatta \%4-12, pazara hazırlık așamasında \%5-15, hallere tașınırken \%2-8, depolamada \%3-10, tüketim așamasında \%1-5 düzeyinde olduğu belirtilmektedir (Kahraman, 2012).

Pazarlama kanallarının çok değișkenli olması ürün fiyatlarında değișikliklere neden olmaktadır. Sektörün kayıt dıșllı̆a uygun olması da ülke ekonomisi açısından istenmeyen bir durumu olușturmaktadır. Bu nedenle üreticilerin satıș kararlarında etkili olan faktörlerin belirlenmesi, toptancı hallere bakıș açılarının değerlendirilmesi önemlidir.
1960 yılından bu yana çeșitli Kanun Hükmünde Kararname ve yasa ile kontrol edilen yaș meyve ve sebze sektörü için son olarak 01.01.2012 tarihinde 5957 sayllı "Sebze ve Meyveler ile Yeterli Arz ve Talep Derinliği Bulunan Diğer Malların Ticaretinin Düzenlenmesi Hakkında Kanun" yürürlüğe girmiștir. Bu kanun özellikle gıda güvenliği ve kayıt sistemi, standardizasyon gibi güncel konuları kapsamaktadır. 5957 sayılı yasa ile yaș meyve ve sebze pazarlamasında oldukça önemli değișiklikler yapılmıștır. Bu değișikliklerden künyeuygulamasının tüm toptancı hallerine getirilmesi, tüketicilere satın aldıkları ürünün nerede, nasıl üretildiğini bilme imkanı sağlamayı hedeflemektedir.

Yasayla birlikte düzenlenen hal kayıt sistemi, halde ve hale biriktirilerek ișlem gören ürünlerin cinsi, miktarı, alıcısı, satıcısı gibi bilgilerin merkezi olarak kayıt altına alınmasını hedeflemektedir. Dolayısıyla ortak bir bilgi ağının yanı sıra, tam anlamıyla kayıt dıșılığın engellenmesi sağlanmıș olacaktır. Yasada kayıt dıșllığı artıran diğer bir önemli sebep olan kesintilerle ilgili düzenlemeler de yapılmıștır. Halde satılan mallardan \%1, hal dıșında satılan mallardan ise \%2 oranında hal rüsumu alınması ve rüsumun artık üreticiden değil satın alandan alınmasına karar verilmiștir. Toptancı hallerinin yeterli etkinliğe kavușması oldukça önemlidir. Illgili düzenlemelerle yaș meyve ve sebze sektörü için önemli adımlar atılmıștır (Resmi Gazete, 2012).

Sayllı ve Civelek (2012), Tokat il merkezindeki toptancı hallerinde görev yapan komisyoncular ve bu toptanc hallerine ürün tedariki sağlayan üreticilerle anket çalıșmaları yapmıșlardır. Araștırmada üreticilerin büyük bir çoğunluğunun yürürlükteki hal yasasından haberdar olmadıkları belirlenmiștir. Komisyoncuların ise hal ile ilgili yasayı büyük oranda bildikleri ve yasayı olumlu olarak tanımladıkları araștırma sonuçları arasındadır. Coșkun ve Tunalıoğlu (2015), Aydın ilinde mevcut 11 adet Toptancı Hal'de faaliyet gösteren toplam 118 komisyoncu ve hal yöneticisinin yeni 5957 sayılı yasa hakkındaki görüșlerini incelemișlerdir. Çalıșmada toptancı hallerde görev yapan yöneticilerin çoğunluğunun, yeni hal yasasının alt yapı eksikliği, bürokrasi ve geçiș süreci nedeniyle etkin olarak uygulanamadığı fikrinde hemfikir oldukları belirlenmiștir. Aydın Can ve Engindeniz (2018), Kocaeli ilinde toptancı halinde görev 
yapan komisyoncular ile yaptıkları bir çalıșmada piyasada sebze ve meyve pazarlanmasında hale giriși yapılmadan tüccar ve direk üreticiden ürün tedariki sağlayan kișilerin olduğunu bu konuda daha sıkı denetimlerin yapılması gerektiğini ifade ettikleri araștırma sonuçları arasında yer almaktadır.

Toptanc haller yaș sebze ve meyve pazarlamasında önemli bir rol üstlenmesi nedeniyle üreticilerin mevcut kanunu ve haklarını bilmeleri önem arz etmektedir. Bununla birlikte toptancı haller hakkındaki görüșlerini bilmek verilecek kararlar için önemlidir. Bu sebeplerden yola çıkarak araștırmanın amaçları;

- 5957 sayılı yasanın üreticiler açısından değerlendirilmesi,

- Ankara Büyükșehir Belediyesi Toptancı Haline ürün veren ve vermeyen üreticilerin karar almalarındaki faktörlerin incelenmesi olarak belirlenmiștir.

\section{MATERYAL VE YÖNTEM}

\section{Materyal}

Araștırma örnek alanı olarak Ankara ili seçilmiș ve yaș meyve sebzede il üretiminin yaklașık \%60'ını gerçekleștiren Polatlı, Beypazarı ve Ayaș ilçelerinde yürütülmüștür. Araștırmanın ana materyalini bu ilçelerde yaș meyve ve sebze üreticileriden yüz yüze anket yöntemiyle elde edilen veriler olușturmuștur.

\section{Yöntem}

\section{Örnekleme sırasında uygulanan yöntem}

Araștırmada Ankara ilinde üreticilik yapan ișletmelerin tamamı ile görüșmek, ekonomik ve teknik açıdan mümkün olamayacağı için örnekleme yapılması uygun görülmüștür ve örneklemede tabakalı örnekleme yöntemi kullanılmıștır. Popülasyonu olușturan 2014 yılı Çiftçi Kayıt Sistemi verilerine göre ișletmelerin kayıtlı ișletme arazisi genișlikleri dikkate alınarak tabakalı örnekleme yöntemine göre \% 90 güven sınırları ile örnek sayıları bulunmuștur (Yamane, 2001).

$$
\mathrm{n}=\frac{\left\lfloor N \sum N_{h} \cdot S_{h}{ }^{2}\right\rfloor}{N^{2} D^{2}+\sum N_{h} \cdot S_{h}{ }^{2}}
$$

$$
\begin{aligned}
& \mathrm{n} \text { = örnek ișletme sayısı } \\
& N_{h}=h^{\prime} \text { ıncı tabakadaki ișletme sayısı } \\
& S_{h}=h^{\prime} ı n c ı \text { tabakanın standart sapması } \\
& \mathrm{N}=\text { Toplam ișletme sayısı } \\
& D^{2}=(d / t)^{2} \text { değeri olup. }
\end{aligned}
$$
hata miktarını (Ortalama arazi genișliğinin \% 10 0'u).

t = Araștırmada öngörülen \%90 güven sınırına karșılık gelen t tablo değerini ifade etmektedir.

Araștırmada anketlerinin yapılacağı ilçeler yaș meyve ve sebze üretim miktarları ile ürün çeșitliliği dikkate alınarak gayeli olarak seçilmiștir. Bu doğrultuda üretici anketlerinin Polatlı, Beypazarı ve Ayaș ilçelerinde yapılmasına karar verilmiștir. Böylelikle yapılacak anket sayısı 122 olarak hesaplanmıștır (Çizelge 1). Anket verileri 2015-2016 üretim dönemine aittir.

Çizelge 1. Anket Yapılan Gruplar ve Anket Sayıları Table 1. Survey Groups and Survey Numbers

\begin{tabular}{lcc}
\hline Da & Varyasyon Katsayısı & Anket Sayısı \\
\hline$<41$ & 39,41 & 34 \\
$41-150$ & 36,00 & 30 \\
$151-400$ & 28,02 & 40 \\
$400+$ & 38,43 & 18 \\
& & Toplam: 122 \\
\hline
\end{tabular}

\section{Verilen analizi sırasında kullanılan yöntem}

Araștırmada üreticilerin kișisel özellikleri, eğitim durumları, satıș yeri tercihleri gibi özellikler basit aritmetik ortalama, yüzde hesapları, grafik, indeks gibi çeșitli tekniklerden yararlanılarak gösterilmiștir. Ceșitli değișkenler ve göstergeler arasındaki ilișkiler $\chi 2$ (Düzgüneș ve ark. 1993, Sokal ve Rohlf 1995) analizi yapılarak açıklanmaya çalıșılmıștır.

\section{BULGULAR VE TARTIȘMA}

İncelenen ișletmelerde üreticilerin ortalama yașı 50,6, ortalama çiftçilik deneyimi 29,5 yıldır. Neredeyse tamamı sosyal güvenceye sahip olup, büyük çoğunluğu ilköğretim seviyesinde eğitim almıșlardır (Çizelge 2). 
Çizelge 2. Üreticilerin Sosyo-Demografik Özellikleri

Table 2. Socio-Demographic Characteristics of Farmers

\begin{tabular}{|c|c|c|c|c|c|c|}
\hline & \multicolumn{5}{|c|}{ Gruplar } & \multirow{2}{*}{ Genel } \\
\hline & & $<41$ & $41-150$ & $151-400$ & $>400$ & \\
\hline Yaș Ortalaması & & 45,6 & 51,2 & 51,0 & 57,9 & 50,6 \\
\hline Çiftçilik Deneyimi (Yıl) & & 21,8 & 30,7 & 31,3 & 38,9 & 50,6 \\
\hline \multirow{2}{*}{ Sosyal Güvence } & Evet & 31 & 29 & 39 & 18 & 117 \\
\hline & Hayır & 3 & 1 & 1 & - & 5 \\
\hline \multirow{4}{*}{ Eğitim } & Yok & - & - & 1 & - & 1 \\
\hline & ì.Ö. & 25 & 26 & 36 & 17 & 104 \\
\hline & Lise & 8 & 4 & 3 & 1 & 16 \\
\hline & Üni. & 1 & - & - & - & 1 \\
\hline
\end{tabular}

Çizelge 3. Üreticilerin Arazi Varlıkları (da)

Table 3. Land Ownership of Farmers (da)

\begin{tabular}{|c|c|c|c|c|c|c|}
\hline \multirow{2}{*}{ Tasarruf Șekli } & \multicolumn{5}{|c|}{ Gruplar } & \multirow{2}{*}{ Ortalam } \\
\hline & & $<41$ & $41-150$ & $151-400$ & $>400$ & \\
\hline \multirow{2}{*}{ Öz Mülk } & $n$ & 23,8 & 87,9 & 193,3 & 474,3 & 161,6 \\
\hline & $\%$ & 39,8 & 82,5 & 92,6 & 98,6 & 88,6 \\
\hline \multirow{2}{*}{ Kiraya Tutulan } & $n$ & 31,0 & 12,0 & 11,7 & 6,7 & 16,4 \\
\hline & $\%$ & 51,8 & 11,2 & 5,6 & 1,4 & 9,0 \\
\hline \multirow{2}{*}{ Ortak } & $n$ & 5,0 & 6,7 & 3,8 & - & 4,3 \\
\hline & $\%$ & 8,4 & 6,3 & 1,8 & & 2,4 \\
\hline \multirow{2}{*}{ Genel } & $n$ & 59,8 & 106,6 & 208,8 & 481,0 & 182,3 \\
\hline & $\%$ & 100,0 & 100,0 & 100,0 & 100,0 & 100,0 \\
\hline
\end{tabular}

İșletmelerde kiraya tutulan arazi varlığı ișletme büyüklüğüyle doğru orantılı olarak azalmaktadır. Birinci grup ișletmelerde ișletme bașına düșen ortalama arazi varlığı 59,8 da olup, \%51,8'ini kiraya tutulan arazi oluștururken bu oran ikinci grup ișletmelerde \%11,2, üçüncü grup ișletmelerde \%5,6 ve dördüncü grup ișletmelerde \% 1,4 oranındadır (Çizelge 3).

İncelenen ișletmelerde en fazla üretilen sebzemeyve ürünleri üretim miktarlarına göre Çizelge 4.'te verilmiștir. İșletmelerde soğan, karpuz ve kavun en çok üretimi yapılan ilk üç üründür. Bu ürünler dıșında ișletmelerde marul, yeșil fasulye, hıyar, taze soğan, ıspanak gibi çok çeșitli ürünlere rastlanılmıștır. Ancak ticari anlamda meyve üretime sadece iki ișletme yer vermekte olup, üretilen kiraz ve dut miktarı oldukça azdır.

Yaș meyve ve sebze sektöründe toptancı hallerinin etkinliğinin artırıması pazarlama kanallarının azalması, üreticilerin ürünlerini daha kolay satması gibi nedenler açısından oldukça önemlidir. Ancak incelenen ișletmelerde

Çizelge 4. Üreticilerin Toplam Sebze Üretimleri (ton)

Table 4. Total Vegetable Production by Farmers (tons)

\begin{tabular}{|c|c|c|c|c|c|c|}
\hline \multirow{2}{*}{ Ürünler } & \multicolumn{5}{|c|}{ Gruplar } & \multirow{2}{*}{ Toplam } \\
\hline & & $<41$ & $41-150$ & $151-400$ & $>400$ & \\
\hline Soğan & Üretim & 971,7 & 2856,4 & 2640,5 & 4261 & 10729,6 \\
\hline Karpuz & Üretim & 881,6 & 2106,5 & 2567,9 & 2602,2 & 8158,2 \\
\hline Kavun & Üretim & 186,5 & 1021,1 & 2682,3 & 3606,7 & 7496,9 \\
\hline Havuç & Üretim & 1254,8 & 779,3 & 576 & - & 2610,1 \\
\hline Domates & Üretim & 1029,6 & 450 & 92,6 & 105 & 1677,2 \\
\hline Kabak & Üretim & 463,5 & 136,5 & 40 & - & 640 \\
\hline Balkabağı & Üretim & 183,6 & 15 & 84,9 & - & 283,5 \\
\hline
\end{tabular}


Çizelge 5. Üreticilerin Yaș Meyve ve Sebze Satıș Yeri Tercihleri

Table 5. Sales Place Preferences of Farmers for Fresh Fruits and Vegetables

\begin{tabular}{|c|c|c|c|c|c|c|}
\hline \multirow{2}{*}{ Satıș Yeri } & \multicolumn{5}{|c|}{ Gruplar } & \multirow{2}{*}{ Ortalama } \\
\hline & & $<41$ & $41-150$ & $151-400$ & $>400$ & \\
\hline \multirow{2}{*}{ Komisyoncu(Hal) } & $\mathrm{n}$ & 6 & 3 & 4 & 2 & 15 \\
\hline & $\%$ & 17,6 & 10,0 & 10,0 & 11,1 & 12,3 \\
\hline \multirow{2}{*}{ Tüccar } & $n$ & 22 & 23 & 35 & 13 & 93 \\
\hline & $\%$ & 64,7 & 76,7 & 87,5 & 72,2 & 76,2 \\
\hline \multirow{2}{*}{ Diğer } & $n$ & 6 & 4 & 1 & 3 & 14 \\
\hline & $\%$ & 17,7 & 13,3 & 2,5 & 16,7 & 11,5 \\
\hline \multirow{2}{*}{ Genel } & $n$ & 34 & 30 & 40 & 18 & 122 \\
\hline & $\%$ & 100,0 & 100,0 & 100,0 & 100,0 & 100,0 \\
\hline
\end{tabular}

$\chi 2=6,860 \quad \mathrm{DF}=6 \quad \mathrm{P}=0,334$

üreticilerin ürün satıșlarında yalnızca \%12,3'ü öncelikli olarak toptanc halini tercih etmekte ve düzenli olarak ürün satmaktadırlar (Çizelge 5.). Üreticilerin \%76.2'si ürünlerini tüccara satarken diğer satıs yeri tercihleri oldukça azdır. Diğer satıș yeri tercihleri doğrudan tüketici $(\% 3,3)$, pazarcı $(\% 4,1)$, ișleme sanayi $(\% 2,5)$ ve kendisi yerel pazarda $(\% 1,6)$ seçeneklerinden olușmaktadır. Ișleme sanayine satıș sadece büyük ölçekli üç ișletmede, üreticinin kendisinin satıșı ise sadece küçük ölçekli iki ișletmede görülmüștür. Kahraman (2012), çalıșmasında dört ürün üzerinde satıș yerlerini incelemiș ve her bir üründe 30 üretici olmak üzere mandalina üreticilerinin \%26.6'sı, patates üreticilerinin \%6.7'si, karpuz üreticilerinin \%13.3'ü, domates üreticilerinin \%40' olmak üzere toplam \%21.6'sının toptancı haline ürün sattığını belirlemiștir. Araștırma sonuçlarımıza paralel olarak aynı çalıșmada üreticilerin büyük çoğunluğunun tüccara ürün satıșı yaptığı belirlenmiștir. Çizelgeden de görüldüğü gibi üreticilerin yaș sebze ve meyve satıș yeri tercihleri ișletme büyüklük gruplarına bağlı olarak değișmemektedir $(\chi 2=6.86, \mathrm{P}=0.334)$.

Üreticilerin \%76,2 gibi büyük bir çoğunluğu ürünlerini tüccar olarak ifade edilen aracılara satmaktadır. Üreticilerin tüccara ürün satıșı kararlarına etkili olan faktörleri anlamak amacıyla üreticilere çeșitli maddeler verilerek katılım durumlarını belirtmeleri istenmiștir. Üreticilerin kararlarını etkileyebileceği düșünülen faktörler, ankete katılan üreticiler tarafından 1'den 5'e kadar derecelendirilmiș ve sonuçları Çizelge 6'da verilmiștir.

Çizelge 6. Üreticilerin Tüccara Ürün Satıs Tercihini Etkileyen Faktörler

Table 6. Factors Affecting of Farmers to Trader Selling Preferences

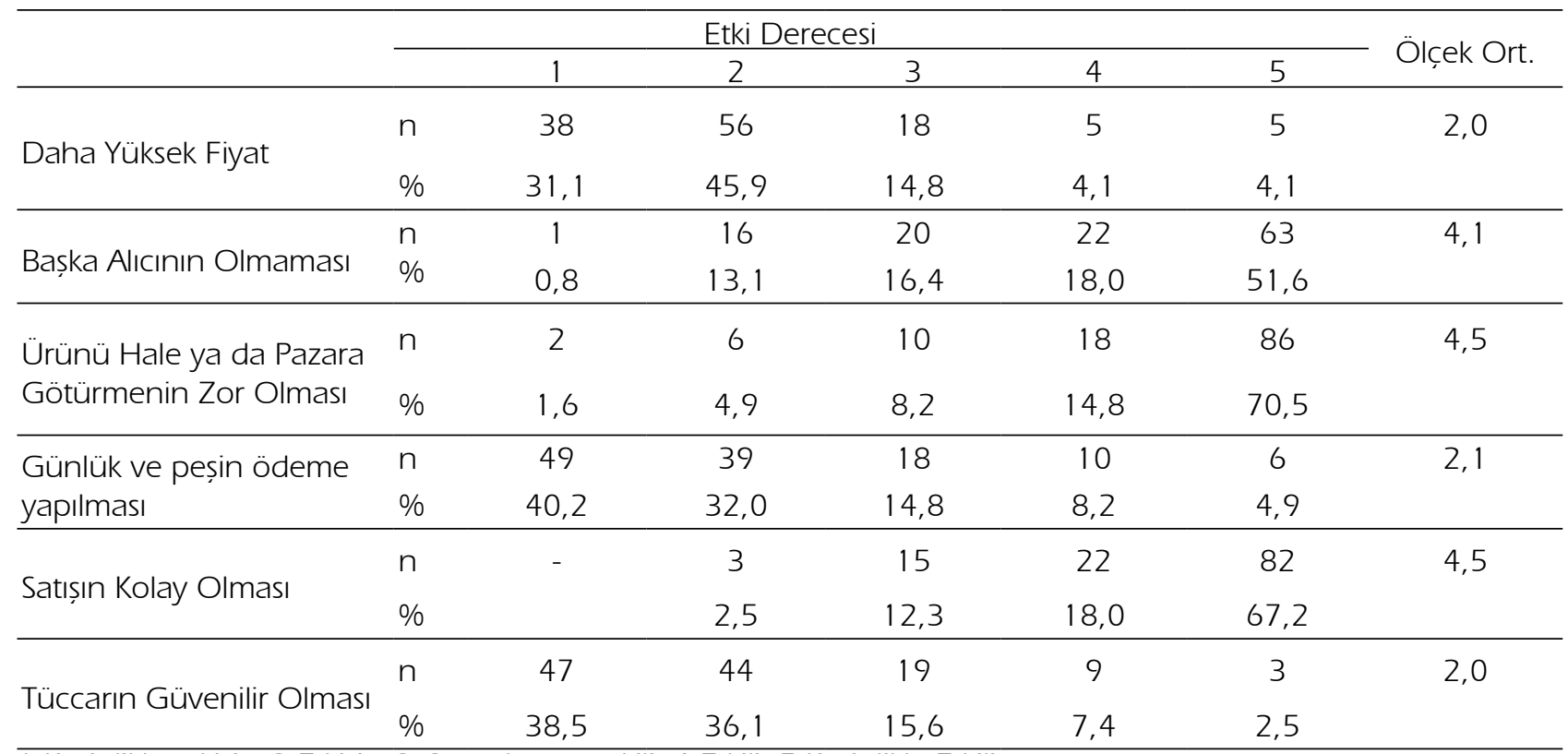

1:Kesinlikle etkisiz, 2:Etkisiz, 3:Orta derece etkili, 4:Etkili, 5:Kesinlikle Etkili 
Çizelge 7. Üreticilerin Toptancı Hallerinden Șikayet Durumları

Table 7. Complaints of Farmers' About Wholesales Market

\begin{tabular}{|c|c|c|c|c|c|c|}
\hline \multirow{2}{*}{ Șikayet Durumu } & \multicolumn{5}{|c|}{ Gruplar } & \multirow{2}{*}{ Genel } \\
\hline & & $<41$ & $41-150$ & $151-400$ & $>400$ & \\
\hline \multirow{2}{*}{$\begin{array}{l}\text { Șikayetim Yok-Hiç Satıș } \\
\text { Yapmadım }\end{array}$} & $\mathrm{n}$ & 10 & 5 & 6 & 6 & 27 \\
\hline & $\%$ & 29,4 & 16,7 & 15,0 & 33,3 & 22,1 \\
\hline \multirow{2}{*}{$\begin{array}{l}\text { Kesintilerin Yüksek } \\
\text { Olması }\end{array}$} & $n$ & 10 & 16 & 15 & 7 & 48 \\
\hline & $\%$ & 29,4 & 53,3 & 37,5 & 38,9 & 39,3 \\
\hline \multirow{2}{*}{ Alıcıların Az Oıması } & $\mathrm{n}$ & 7 & 8 & 19 & 4 & 38 \\
\hline & $\%$ & 20,6 & 26,7 & 47,5 & 22,2 & 31,1 \\
\hline \multirow{2}{*}{$\begin{array}{l}\text { Diğer (İșlem Zorluğu, } \\
\text { Yer Darlığı) }\end{array}$} & $\mathrm{n}$ & 7 & 1 & - & 1 & 9 \\
\hline & $\%$ & 20,6 & 3,3 & & 5,6 & 7,4 \\
\hline \multirow{2}{*}{ Toplam } & $n$ & 34 & 30 & 40 & 18 & 122 \\
\hline & $\%$ & 100,0 & 100,0 & 100,0 & 100,0 & 100,0 \\
\hline
\end{tabular}

Çizelge 6 incelendiğinde, sırasıyla ürünü hale ya da pazara götürmenin zor olması, satıșın kolay olması ve bașka alııının olmaması faktörlerinin oldukça etkili olduğu görülmektedir. Yapılan benzer araștırmalarda da satıșın kolay olması en önemli etken olarak bulunmuștur (Kahraman, 2012). Üreticilerin toptancı haline ürün satıșını etkileyen en önemli faktörün ise parayı alma garantisi olduğu belirlenmiștir. Ancak üreticiler daha yüksek fiyat, günlük ve peșin ödeme yapııması ile tüccarın güvenilir olması maddelerine katılmadıklarını belirtmișlerdir.

Üreticilerin toptancı haline ürün satıșı yapmamalarının nedenlerini anlamak, ürün satan üreticilerin toptancı halinden șikayet durumları belirlenerek Çizelge 7'de verilmiștir. Üreticilerin \%39,3'ü kesintilerin fazla olmasından, \%31,1'i ise alıcıların az olmasından șikayetçi olduğunu belirtmiștir. Üreticilerden 27 birey șikayetim yok-hiç satıș yapmadım tercihini seçerken, bu üreticilerden 19 bireyin toptancı haline daha önce hiç satıș yapmadığı belirlenmiștir. Üreticilerin toptancı halinden șikayet durumunun ișletme büyüklük gruplarından bağımsız olmadığı belirlenmiștir $\mid \mathrm{G}=$ $22,679, P=0,007$.

Üreticilerin gelecek üretim dönemlerinde toptancı haline ürün verme düșünceleri incelendiğinde büyük çoğunluğunun ürün verme düșüncesinde olmadığı belirlenmiștir (Çizelge 8.). Birinci grup ișletmelerde üreticilerin \%35.3'ü vermeyi düșündüğü görülmektedir. Büyük arazi sahiplerinin ise görüșlerinde daha katı oldukları ve \%94,4'ünün ürün vermeyi düșünmedikleri görülmüștür. Bunun nedeni olarak dördüncü grup ișletmelerin üretim miktarının çokluğu, yaș ortalamasının yüksekliği ve yıllardır alıștıkları bir pazarlama sistemlerinin olması olarak düșünülebilir. Ki-kare testi sonucunda üreticilerin toptancı haline ürün verme düșüncelerinin ișletme büyüklüğüne bağlı olarak değiștiği görülmüștür $\left(\chi^{2}=11,236 \quad P=0,011\right)$.

Çizelge 8. Üreticilerin Gelecekte Toptancı Haline Ürün Satma Düșünceleri

Table 8. Farmers' Thought About Sales the Product to Wholesales Market in The Future

\begin{tabular}{|c|c|c|c|c|c|c|}
\hline \multirow{2}{*}{ Ürün Verme Düșüncesi } & \multicolumn{5}{|c|}{ Gruplar } & \multirow{2}{*}{ Ortalama } \\
\hline & & $<41$ & $41-150$ & $151-400$ & $>400$ & \\
\hline \multirow{2}{*}{ Evet } & $n$ & 12 & 3 & 5 & 1 & 21 \\
\hline & $\%$ & 35,3 & 10,0 & 12,5 & 5,6 & 17,2 \\
\hline \multirow{2}{*}{ Hayır } & $\mathrm{n}$ & 22 & 27 & 35 & 17 & 101 \\
\hline & $\%$ & 64,7 & 90,0 & 87,5 & 94,4 & 82,8 \\
\hline \multirow{2}{*}{ Toplam } & $n$ & 34 & 30 & 40 & 18 & 122 \\
\hline & $\%$ & 100,0 & 100,0 & 100,0 & 100,0 & 100,0 \\
\hline
\end{tabular}


Çizelge 9. Üreticilerin Hal Yasasından Haberdar Olma Durumları

Table 9. Farmers' Whether Knowing or not About Law The Number 5957

\begin{tabular}{lcccccc}
\hline \multirow{2}{*}{$\begin{array}{l}\text { Hal Yasasınından } \\
\text { Haberdar Olma }\end{array}$} & \multicolumn{5}{c}{ Gruplar } & \multirow{2}{*}{ Genel } \\
\cline { 2 - 6 } Evet & $\mathrm{n}$ & 5 & $41-150$ & $151-400$ & $>400$ & 6 \\
& $\%$ & 14,7 & - & 1 & - & 4,9 \\
\hline \multirow{2}{*}{ Hayır } & $\mathrm{n}$ & 29 & 30 & 39 & 18 & 116 \\
\hline \multirow{2}{*}{ Toplam } & $\%$ & 85,3 & 100,0 & 97,5 & 100,0 & 95,1 \\
\hline $\mathrm{G}=10,100$ & $\mathrm{DF}=3$ & 34 & 30 & 40 & 18 & 122 \\
& $\%$ & 100,0 & 100,0 & 100,0 & 100,0 & 100,0 \\
\hline
\end{tabular}

Incelenen ișletmelerde üreticilerin neredeyse tamamının 5957 sayılı yasadan haberdar olmadıkları belirlenmiștir (Çizelge 9). Küçük ișletmelerde kısmen yasadan haberdar olma durumu diğer grup ișletmelere göre daha fazladır. Yasadan haberdar olan toplam 6 üreticinin yasa ile ilgili bildiklerinin künye uygulaması ve laboratuvar kurma zorunluğu olduğu gözlemlenmiștir. Gözener ve Sayılı (2011) çalıșmalarında Tokat ilinde faaliyet gösteren komisyoncuların \%43.48'inin hiç haberinin olmadığı, \%50.00'sinin sadece duydukları ve \%6.52'sinin ise yasa hakkında tam bir bilgiye sahip olduğunu tespit etmișlerdir.

Büyük çoğunluğu yasadan haberdar olmayan üreticilere yasadaki değișiklikler anlatılarak maddeleri 1'den 5'e kadar derecelendirmeleri istenmiștir. Cevapların her madde için ağırlıklı ortalama ile dereceleri hesaplanmıș ve çizelge 10'da verilmiștir. Üreticilerin büyük çoğunluğu yasayı olumlu olarak değerlendirmiș ancak sözlü olarak yasanın uygulamada geçerli olmayacağına inandıklarını belirtmișlerdir.

Üreticilerin ilk olarak 4,2 derecesinde olumlu bulduğu maddeler hal kayıt sisteminin kurulması ve hal içi ve dıșı ișlem maliyetlerinin azaltılması ve toptancı hallerindeki ișyerleri ile semt pazarlarındaki satıș yerlerinin en az \%10'unun üretici ve üretici örgütlerine ayrılması olarak belirlenmiștir. Diğer maddeler incelendiğinde üreticilerin kendilerini doğrudan ilgilendirmeyen konularda kararsız ya da olumsuz görüș bildiren üreticilerin arttığı gözlemlenmiștir.

Yasada yapılan değișiklikler arasında toptancı haline bildirimde bulunmak kaydıyla toptancı hali dıșında da toptan mal alınıp satılabilmesi maddesine üreticilerin çoğunluğu olumsuz görüș bildirmiștir. Üreticilerin ürünlerin toptancı hali dıșında satılması konusunda çekincelere sahip olduğu gözlemlenmiștir. Bunun nedeni olarak yapılan sözlü sorgulamada bu maddenin üreticiyi olumsuz etkileyeceği, tüccar ve komisyoncuların üreticiden habersiz fiyat belirleyeceğini düșünmeleri ön plana çıkmıștır.

Üreticiler tarafından Çizelge 10'da verilen maddelerin tamamı için \%67.1'i olumlu görüș bildirilmiștir. Bu oranın içinde \%42.8'i kesinlikle olumlu , \%24,3'ü olumlu görüștür. Bununla birlikte görüșlerin yalnızca 20.5'i olumsuz iken, \%12.5'i kararsız görüștür (Șekil 1). Bir bașka araștırmada Aydın ili yaș meyve ve sebze halinde çalıșan komisyoncular ile görüșülmüș ve komisyoncuların \%41.9'unun 5957 sayılı yasa hakkındaki düșüncelerinin olumlu, \%41.9'unun olumsuz ve \%16.3'ünün ise belirsiz olduğu tespit edilmiștir (Coșkun, 2014).

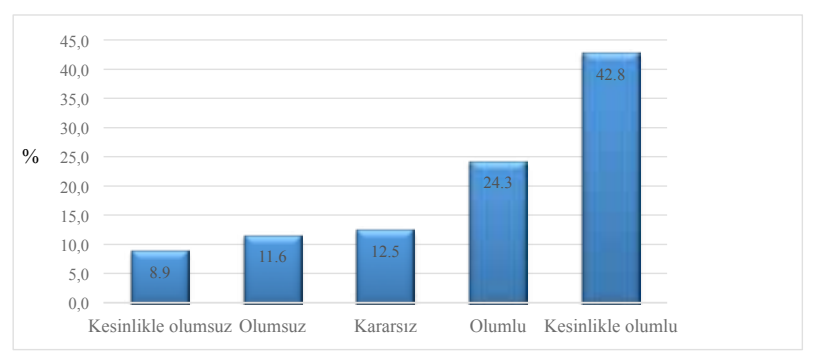

Șekil 1. Üreticilerin 5957 Sayılı Yasa Hakkındaki Görüșleri

Figure 1. Farmers' Views About Law No. 5957

Toptancı hallerinin etkinliğinin artırıması pazarlama kanallarının kısalması, ekonomik kayıpların azalması, ürünlerin kayıt altına alınması için oldukça önemlidir. Bu nedenle üreticilerin toptancı hallerinde rol oynaması 
Çizelge 10. Üreticilerin 5957 Sayılı Yasa Hakkındaki Görüșleri

Table 10. Farmers' Views About Law No. 5957

\begin{tabular}{|c|c|c|c|c|c|c|c|}
\hline & \multicolumn{5}{|c|}{ Etki Derecesi } & \multirow[b]{2}{*}{5} & \multirow{2}{*}{ Ölçek Ort. } \\
\hline & & 1 & 2 & 3 & 4 & & \\
\hline \multirow{2}{*}{$\begin{array}{l}\text { Toptancı haline bildirimde bulunmak kaydıyla } \\
\text { toptancı hali dıșında da toptan mal alınıp } \\
\text { satılabilmesi }\end{array}$} & $\mathrm{n}$ & 31 & 39 & 14 & 22 & 16 & \multirow[t]{2}{*}{2,6} \\
\hline & $\%$ & 25,4 & 32,0 & 11,5 & 18,0 & 13,1 & \\
\hline \multirow{2}{*}{ Hal kayıt sisteminin kurulması } & $\mathrm{n}$ & 5 & 10 & 10 & 30 & 67 & \multirow[t]{2}{*}{4,2} \\
\hline & $\%$ & 4,1 & 8,2 & 8,2 & 24,6 & 54,9 & \\
\hline \multirow{2}{*}{ Hal içi ve dıșı ișlem maliyetlerinin azaltılması } & $\mathrm{n}$ & 5 & 9 & 7 & 39 & 62 & \multirow[t]{2}{*}{4,2} \\
\hline & $\%$ & 4,1 & 7,4 & 5,7 & 32,0 & 50,8 & \\
\hline \multirow{2}{*}{$\begin{array}{l}\text { Hal hakem heyetleri yeniden yapılandırıması } \\
\text { ve değeri } 50000 \text { tl altındaki uyușmazlıklarda } \\
\text { heyete bașvurmanın zorunlu olması }\end{array}$} & $\mathrm{n}$ & 10 & 12 & 25 & 37 & 38 & \multirow[t]{2}{*}{3,7} \\
\hline & $\%$ & 8,2 & 9,8 & 20,5 & 30,3 & 31,1 & \\
\hline \multirow{2}{*}{ Künye uygulamasının getirilmesi } & $n$ & 7 & 8 & 10 & 53 & 44 & \multirow[t]{2}{*}{4,0} \\
\hline & $\%$ & 5,7 & 6,6 & 8,2 & 43,4 & 36,1 & \\
\hline \multirow{2}{*}{$\begin{array}{l}\text { Halde satılan mallardan \%1. hal dıșında } \\
\text { satılan mallardan ise \% } 2 \text { oranında hal } \\
\text { rüsumu alınması }\end{array}$} & $\mathrm{n}$ & 19 & 35 & 27 & 23 & 18 & \multirow[t]{2}{*}{2,9} \\
\hline & $\%$ & 15,6 & 28,7 & 22,1 & 18,9 & 14,8 & \\
\hline \multirow{2}{*}{$\begin{array}{l}\text { Rüsumun artık üreticiden değil satın alandan } \\
\text { alınması }\end{array}$} & $\mathrm{n}$ & 11 & 13 & 4 & 28 & 66 & \multirow[t]{2}{*}{4,0} \\
\hline & $\%$ & 9,0 & 10,7 & 3,3 & 23,0 & 54,1 & \\
\hline \multirow{2}{*}{$\begin{array}{l}\text { Üreticilerce kurulan tüm tüzel kișiliklerin } \\
\text { üretici örgütü olarak kabul edilebilmesi }\end{array}$} & $n$ & 9 & 9 & 7 & 34 & 63 & \multirow[t]{2}{*}{4,0} \\
\hline & $\%$ & 7,4 & 7,4 & 5,7 & 27,9 & 51,6 & \\
\hline \multirow{2}{*}{$\begin{array}{l}\text { Toptancı hallerindeki ișyerleri ile semt } \\
\text { pazarlarındaki satıș yerlerinin en az \%20'sinin } \\
\text { üretici ve üretici örgütlerine ayrılması }\end{array}$} & $n$ & 8 & 7 & 11 & 25 & 71 & \multirow[t]{2}{*}{4,2} \\
\hline & $\%$ & 6,6 & 5,7 & 9,0 & 20,5 & 58,2 & \\
\hline \multirow{2}{*}{$\begin{array}{l}\text { Üretici örgütlerinin rüsum ödemeksizin } \\
\text { toptancı hali dıșında da toptan olarak vergi } \\
\text { mükelleflerine satıș yapabilmesi }\end{array}$} & $n$ & 6 & 12 & 14 & 34 & 56 & \multirow[t]{2}{*}{4,0} \\
\hline & $\%$ & 4,9 & 9,8 & 11,5 & 27,9 & 45,9 & \\
\hline $\begin{array}{l}\text { Sanayi ve ticaret bakanlığı özellikle üretici } \\
\text { haklarının korunması amacıyla alım-satım } \\
\text { ișlemlerini düzenleyen sözleșmelerde } \\
\text { bulunması gerekli asgarî șartları } \\
\text { belirleyebilmesi }\end{array}$ & $\%$ & 12,3 & 15,6 & 15,6 & 14,8 & 41,8 & 3,6 \\
\hline \multirow{2}{*}{$\begin{array}{l}\text { Toptancı hali kurma faaliyetlerinin disiplin } \\
\text { altına alınması }\end{array}$} & $n$ & 7 & 6 & 34 & 34 & 41 & \multirow[t]{2}{*}{3,8} \\
\hline & $\%$ & 5,7 & 4,9 & 27,9 & 27,9 & 33,6 & \\
\hline $\begin{array}{l}\text { Toptancı Hali Konseyi'nin olușturulup } \\
\text { konseye temsilci verecek olan kamu } \\
\text { kurumları. üretici ve tüketici örgütleri ile } \\
\text { sivil toplum ve meslek kurulușları arasında } \\
\text { uygulamaya yönelik ișbirliği sağlanması }\end{array}$ & $\%$ & 5,7 & 10,7 & 21,3 & 28,7 & 33,6 & 3,7 \\
\hline \multirow{2}{*}{$\begin{array}{l}\text { Toptancı hallerinde müzayede depolama. } \\
\text { tasnifleme ve ambalajlama tesisleri ile } \\
\text { laboratuvarlar kurulması zorunluluğu }\end{array}$} & $\mathrm{n}$ & 11 & 10 & 8 & 15 & 78 & \multirow[t]{2}{*}{4,1} \\
\hline & $\%$ & 9,0 & 8,2 & 6,6 & 12,3 & 63,9 & \\
\hline \multirow{2}{*}{$\begin{array}{l}\text { Hale giren ve çıkan mallarda standardizasyon } \\
\text { uygulamalarının bulunması }\end{array}$} & $n$ & 11 & 10 & 13 & 17 & 71 & \multirow[t]{2}{*}{4,0} \\
\hline & $\%$ & 9,0 & 8,2 & 10,7 & 13,9 & 58,2 & \\
\hline
\end{tabular}

1:Kesinlikle etkisiz, 2:Etkisiz, 3:Orta derece etkili, 4:Etkili, 5:Kesinlikle Etkili 
Çizelge 1 1. Üreticilerin Toptancı Haline Ürün Vermek İçin Beklentileri

Table 11. Farmers' Expectations for Sale of Products to Wholesales Market

\begin{tabular}{|c|c|c|c|c|c|c|}
\hline \multirow{2}{*}{ Beklenti } & \multicolumn{5}{|c|}{ Gruplar } & \multirow{2}{*}{ Gene } \\
\hline & & $<41$ & $41-150$ & $151-400$ & $>400$ & \\
\hline \multirow{2}{*}{ Hiçbir Șekilde Vermem } & $n$ & 10 & 10 & 20 & 11 & 51 \\
\hline & $\%$ & 29,4 & 33,3 & 50,0 & 61,1 & 41,8 \\
\hline \multirow{2}{*}{ Fiyat Yüksek Olursa } & $\mathrm{n}$ & 7 & 2 & 1 & 1 & 11 \\
\hline & $\%$ & 20,6 & 6,7 & 2,5 & 5,6 & 9,0 \\
\hline \multirow{2}{*}{$\begin{array}{l}\text { Güvenilir komisyoncu } \\
\text { olursa }\end{array}$} & $\mathrm{n}$ & 1 & 1 & - & - & 2 \\
\hline & $\%$ & 2,9 & 3,3 & & & \\
\hline \multirow{2}{*}{ Kesintiler Kaldırılırsa } & $\mathrm{n}$ & 2 & 8 & 3 & 3 & 16 \\
\hline & $\%$ & 5,9 & 26,7 & 7,5 & 16,7 & 13,1 \\
\hline \multirow{2}{*}{ Nakliye Hizmeti Sağlanırsa } & $\mathrm{n}$ & 8 & 5 & 7 & 2 & 22 \\
\hline & $\%$ & 23,5 & 16,7 & 17,5 & 11,1 & 18,0 \\
\hline \multirow{2}{*}{$\begin{array}{l}\text { Toptancı Hali Yakında } \\
\text { Olursa }\end{array}$} & $\mathrm{n}$ & 3 & 3 & 9 & 1 & 16 \\
\hline & $\%$ & 8,8 & 10,0 & 22,5 & 5,6 & 13,1 \\
\hline \multirow{2}{*}{$\begin{array}{l}\text { Her Șekilde Vermeye } \\
\text { Devam Ederim }\end{array}$} & $\mathrm{n}$ & 3 & 1 & - & - & 4 \\
\hline & $\%$ & 8,8 & 3,3 & & & 3,3 \\
\hline \multirow{2}{*}{ Toplam } & $\mathrm{n}$ & 34 & 30 & 40 & 18 & 122 \\
\hline & $\%$ & 100,0 & 100,0 & 100,0 & 100,0 & 100,0 \\
\hline
\end{tabular}

istenilen bir unsurdur. Bu etkinliği artırmak için incelenen ișletmelerde üreticilerin toptancı haline ürün vermek için beklentileri açık uçlu sorularla değerlendirilmiș ve benzer cevaplar gruplandırımıștır. Çizelge 11 'de görüldüğü gibi üreticilerin \%41.8'i hiçbir șekilde vermem yanıtını verirken bu yanıtı verenlerin çoğunluğunun büyük ișletmelerde olduğu, birinci grup ișletmelerde ise bu yanıtı verenlerin grubun \%29.4'ünü olușturduğu belirlenmiștir. Toptancı haline ürün vermek için beklentilerin ișletme büyüklük gruplarından bağımsız olmadığı görülmüștür $\mid \mathrm{G}=$ $30.673 P=0.031$ ).

\section{SONUC̣LAR}

Yaș meyve ve sebze gibi tüketiciye hızlı, en az zayiatla ulașması gereken ürünlerde pazarlama zincirinin uzaması üreticinin ve tüketicinin maddi zarara uğramasına neden olmaktadır. Toptancı halleri yaș meyve ve sebze sektöründe oldukça önemli bir pazarlama kanalıdır. Hallerin etkinliğinin artırıması sadece ekonomik kayıplar açısından değil, aynı zamanda ürünlerin kayıt altına alınabilmesi, izlenebilirliği gibi birçok nedenle önemlidir. Ancak araștırmada yaș meyve ve sebze satıșında üreticilerin yalnızca \%12.3'ü toptanc haline ürün vermeyi tercih etmekte iken \%76.2'si tüccara ürün satıșını tercih etmektedir.

Üreticilerin yalnızca \%4.9’u 5957 sayllı yasadan haberdardır. Dolayısıyla doğrudan üreticiyi ilgilendiren yasal düzenlemelerde üreticiye yeteri kadar ulașılamadığı anlașılmaktadır. Yasanın bilinmemesi, üreticilerde eski yasal düzenlemelerden gelen memnuniyetsizlik ile birlikte toptancı haline ürün satıșlarını olumsuz etkilediği düșünülmektedir.

Yasadaki değișikliklere üreticilerin \%67.1'i olumlu, \%20.5'i olumsuz görüș bildirmiș ve hal kayıt sisteminin kurulması, hal içi ve dıșı ișlem maliyetlerinin azaltıması, toptancı hallerindeki ișyerleri ile semt pazarlarındaki satıș yerlerinin üretici örgütlerine en az \%20 oranında yer verilmesi maddeleri ön plana çıkmıștır.

Üreticilerin toptancı haller ile ilgili bu olumsuz algısının nedeni çoğunlukla daha önce yaptıkları satıșlarda sorun yașamaları olduğu anlașılmıștır. Üreticilerin \%18'i nakliye hizmetinin sağlanması 
durumunda ürün vereceklerini belirtmișlerdir. Bu konudaki beklenti ise ilgili bir üretici örgütü kurulması ve üretici örgütünün toptancı halinde satıș yapması ile giderilebilir.

İncelenen ișletmelerde tüccara ürün satıșını etkileyen en önemli faktörler ürünü hale ya da pazara götürmenin zor olması, satıșın kolay olmasıdır. Üreticilerin bulundukları șehirler yerine uzak mesafedeki șehirlere ürün satıșı ürün fiyatını artırmakta, üreticinin kazancını azaltmaktadır. Üstelik bu durum haksız rekabete yol açtığı gibi ekonomik kayıplara da neden olmaktadır. Dengeli bir pazarlama anlayıșı için etkin bir pazarlama stratejisi geliștirilmelidir. Konuyla ilgili araștırmalar artırılmalı, üreticiler bilgilendirilmeli ve ekonomik kayıpların önüne geçecek önlemler alınmalıdır.

\section{TEȘEKKÜR}

Bu makale Tarım ve Orman Bakanlığı Tarımsal Araștırmalar ve Politikalar Genel Müdürlüğü tarafindan desteklenen TAGEM/TEAD/14/A15/ P01/001 numaralı projeden üretilmiștir. Destekleri için teșekkür ederim.

\section{KAYNAKLAR}

Albayrak M (2009). Yaș Meyve ve Sebze Pazarlama Merkezleri: Toptancı Haller - Pazarlar (Dünya, Avrupa Birliği ve Türkiye'den Örneklerle Yapısı ve İșleyișii). Tarım ve Köy İșleri Bakanlığı, Tarımsal Ekonomi Araștırma Enstitüsü Yayını, Yayın No:177, Ankara.

Anonim (2013). http://www.tuik.gov.tr. Erișim Tarihi: 20.10 .2013
Anonim (2016a). https://mww.tarimdanhaber.com Erișim Tarihi: 10.11.2016

Aydın Can B, Engindeniz S (2018). Tarım Ürünlerinin Pazarlanmasında Toptancı Hallerinin Rolü ve Önemi: Kocaeli Merkez İlçe Toptancı Hali Örneği. Selçuk Tarım ve Gıda Bilimleri Dergisi (2018) 32 (3), 266-273. Konya.

Coșkun M. H (2014). Aydın Illinde Yaș Sebze ve Meyve Toptancı Hallerinin İncelenmesi. Adnan Menderes Üniversitesi Fen Bilimleri Enstitüsü Yüksek Lisans Tezi.

Coșkun M. H, Tunalıoğlu R (2015). Aydın Illinde Yaș Sebze ve Meyve Toptanc Hallerinin İncelenmesi. Adnan Menderes Üniversitesi Ziraat Fakültesi Dergisi 2015; 12(2):83-92. Aydın.

Düzgüneș O, Kesici T, Gürbüz F (1993). İstatistik Metotları (II. Baskı). Ankara Üniversitesi Ziraat Fakültesi Yayınları No:1291, Ders Kitabı: 369, 218 s., Ankara

Kahraman E (2012). Türkiye'de Yas Meyve-Sebze Pazarlamasında Toptancı Hallerinin Etkinliği, Karșılașılan Sorunlar ve Çözüm Önerileri: İzmir İli Örneği. Ege Üniversitesi Fen Bilimleri Enstitüsü Tarım Ekonomisi Ana Bilim Dalı Yüksek Lisans Tezi.

Resmi Gazete (2012). http://www.resmigazete.gov.tr Erișim Tarihi: 21.08.2013

Sokal R.R, Rohlf F.J (1995). Biometry. The principles and practice of statistics in biological research. Third edition. W.H. Freeman Company. New York.

Sayılı M, Civelek O (2012). Tokat Ili Merkez İlçede Yaș Sebze ve Meyve Toptancı Halinin Yapısı, Sorunları ve Çözüm Önerileri. Gıda Tarım ve Hayvancılık Bakanlığı Tarım Ekonomisi Araștırma Enstitüsü Yayınları ISBN: 978-975-407346-1.

Yamane T (2001). Temel Örnekleme Yöntemleri. (Birinci Baskı). Ceviren: Alptekin Esin, M. Akif Bakır, Celal Aydın ve Esen Gürbüzsel. İstanbul. Literatür Yayıncılık. 